\title{
Midwest Education, Inc.: An International Human Resource Management Case Study
}

Arthur K. Fischer, (Email: artfisch@ pittstate.edu), Pittsburg State University

\begin{abstract}
An HRM case dealing with problems encountered in global operations is presented. Discussion concerns how such a case can be used to exhibit the alignment between HRM and business strategy. This case study is appropriate for any human resource management class.
\end{abstract}

\section{INTRODUCTION}

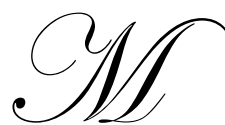

idwest Education, Inc. is a major supplier of educational materials for the United States and much of the world. The company focus is on learning tools and systems for use in technology, science and business classrooms. In addition, it develops and provides books, manuals, videos, software and hardware used in the fields of technology education, instructional development and business applications.

The company has its headquarters and primary manufacturing plant in a major Midwest community. In addition, the Creative Development offices are located in Massachusetts and California. Transportation, Service and Maintenance facilities are headquartered out of Texas, with major branches in Baltimore and Phoenix. Other sections of these divisions are located in Germany and China to handle international operations.

The three main functional divisions exemplify three different strategies: cost-reduction, quality enhancement, and innovation (as discussed by Schuler and Jackson, 1987).

\section{Transportation, Service and Maintenance}

The primary strategy of the Transportation, Service and Maintenance Division is cost-reduction. Midwest Education, Inc. has long been known for providing service and maintenance programs which are very reasonably priced.

\section{Manufacturing}

The primary strategy of the Manufacturing Division is quality enhancement. Midwest education, Inc. has an enviable history of providing the highest quality products which have been adopted by first-rate schools and corporate training programs.

\section{Creative Development}

The primary strategy of the Creative Development Division is innovation. Midwest Education, Inc. is widely known for providing truly cutting edge teaching materials which always mirror the latest techniques and processes.

\section{COMPANY HISTORY}

Midwest Education was started by Henry and Mary Dalton in 1975. Dr. Henry Dalton was an industrial arts 
$\underline{1}$ teacher before he got his MBA and went on to get his Ph.D. in Technology Education. Mary was a software developer who also taught business seminars. At that time a new wave of emerging technology was beginning to alter the way people learn and communicate. In developing Midwest Education, Inc. the Daltons began work in an exciting new field. They found a vast market for quality tools that educated people on how to use all the new technology. Dr. and Mrs. Dalton are in semi-retirement now and travel extensively, but remain major shareholders in the business. They personally hired the CEO when they went into semi-retirement.

The company started with about fifty employees, but has grown consistently and now has a total of 416 employees within its three major divisions: 158 employees work in the Manufacturing Division, 123 work in the Creative Development Division and 135 work in the Transportation, Service and Maintenance Division. There are also 135 employees working at the headquarters in Kansas City (including the corporate staff).

At the beginning of the 1990s it became apparent that international business was becoming the rule rather than the exception. The company went international in 1994 and now is exporting to three European, two Latin American, and two Pacific Rim countries. The Global Operations Department was created as a subsidiary of and is now located within the headquarters.

\section{Headquarters}

The corporate headquarters are in Kansas City. The CEO of Midwest Education, Inc. is Judith Lund. Ms Lund was hired by the Daltons in 1998 when they decided to take a less active role in the company while remaining major shareholders. Ms. Lund has an MBA in business management, and was previously the CEO of a small telecommunications company. In her previous position, Ms Lund had successfully steered the company out of financial difficulties by raising stock value. She had initiated a strong advertising campaign and had put the company 'in the black' for the first time in seven years.

The COO of Midwest Education, Inc. is Frank Rose. Frank has been with the company since 1989. Mr. Rose, a cousin of Dr. Dalton, had a successful career with an international business training group in California. His desire to move back to his home town of Kansas City came at a time when the Daltons were looking for a COO. He has worked out well for the company.

The Human Resources Department is also located at the headquarters. The Vice President for Human Resources is Lawrence Wilson. Mr. Wilson has a degree in industrial and organizational psychology and an MBA. He has been with the company for 11 years. He started out as a generalist and was promoted as he showed good judgment with hiring and earned his MBA at the same time.

Within the Human Resources Department there are four sections:

1. Staffing, the head of this section is Patrick Shew.

2. Compensation and benefits section, headed by Michael Martin.

3. $\quad$ Labor management relations section, headed by Keith Lane.

4. Training, career development and performance appraisal section, headed by Cynthia Burns.

There are also human resource specialists in each of the three divisions around the country and in the two international sections.

\section{Manufacturing Division}

The mission statement for the Manufacturing Division is:

"The aim of the Manufacturing Division of Midwest Education, Inc. is to continually improve the quality and strength of all our products. The superior products for which we have become world renowned will still be manufactured, 
$\underline{1}$

along with new and innovative products and ideas. We will work hard to keep quality high and cost down while supplying customers with the best possible products in the shortest possible time." The Manufacturing Division follows a strategy of quality enhancement.

The main manufacturing plant is located on the outskirts of Kansas City, not far from the company headquarters. The president of the Manufacturing Division is Max Thorn. Mr. Thorn has been with the company almost since its inception. He was one of the first employees hired by the Daltons. He started writing programs for the company and originally worked alongside the Daltons in interviewing and hiring many other employees.

The head of human resources for the Manufacturing Division is Janine Woods. She has a staff of five generalists who assist her in meeting HRM needs for the Manufacturing Division.

The Manufacturing Division used to be housed in the same building as the headquarters. As the business expanded and more room was needed, the division moved to the suburbs into a large factory site. There are 158 employees in the Manufacturing Division. They are divided into ten teams, each team works at producing and packaging a specific product at a time. There are five supervisors who each supervise two teams: Doris Malone, John Fizer, Sandi Cross, Wendy Atchison, and Ian Carpenter.

The Manufacturing Division usually has a long lead time on orders and can anticipate what will be needed. The factory has flexible work areas that can be re-tooled and rearranged for the changeover from one product to another in less than four hours. The pay in this Division starts at $\$ 6.25 / \mathrm{hr}$ for production workers and has a full benefits package. Most employees seem happy with their work. Max Thorn is generally thought of as a good, easy-going man to work for.

\section{Creative Development Division}

The mission statement for the Creative Development Division is:

"In the Creative Development Division of Midwest Education, Inc. we will strive to bring our customers the most innovative and cutting edge programs and products in the world. Our team of creative professionals is constantly working to improve, upgrade, and create the most useful products to bring to our customers." This division follows a strategy of innovation.

The Creative Development Division has two locations; a headquarters in California and a branch located in Massachusetts. The president of the Creative Development Division is Serena Tibaldo. Ms. Tibaldo recently joined the company. Previously she was a software developer for a large computer game producer. She has a bachelor's degree in business and a computer programming master's degree, and is doing very well at Midwest.

The head of human resources for the Creative Development Division is Amelia Chi, who is located at the California headquarters. Ms. Chi has a staff of five assistants. The head of the human resource section at the Massachusetts branch is Virginia Fox. Ms Fox has a staff of two assistants.

There are 90 people employed at the California plant and 38 at the Massachusetts location. The California location opened in 1980 and the Massachusetts branch was opened in 1993. In the 1970's and 1980's many computer software programmers moved to the west coast to be located in Silicon Valley. Most people hired by Midwest Education, Inc. transferred from wherever they lived to the California branch, with the company paying all relocation expenses. By 1990 some employees desired to live in the east. The Daltons decided it was time to expand the company and in doing so decided the next branch would be in the Massachusetts area. Most of the long time personnel elected to remain California. The majority of recent hires are in Massachusetts. 


\section{$\underline{1}$ Transportation, Service And Maintenance Division}

The mission statement for the Transportation, Service and Maintenance Division is:

"The Transportation, Service, and Maintenance Division is committed to providing the fastest and most cost effective way of safely shipping our product to our customers. No effort will be spared as we streamline and improve our fast and friendly service". The Transportation, Service and Maintenance Division follows a strategy of cost-reduction.

The Transportation, Service and Maintenance Division headquarters is located in San Antonio, Texas. There are major branches in Baltimore, Maryland and Phoenix, Arizona. The President of the Transportation, Service and Maintenance Division is Mark Derrick. Mr. Derrick is based in San Antonio. Mr. Derrick has been with Midwest Education, Inc. for 13 years. He personally hires the managers for the other branches in Maryland and Arizona.

The head of human resources for the Transportation, Service and Maintenance Division is Salvador Vasquez. Mr. Vasquez has a staff of five assistants. Mr. Vasquez appoints HR heads to the other branches. Often they are employees from San Antonio that he knows well and trusts.

The Transportation, Service and Maintenance Division was originally based in Kansas City. As the company grew a decision was made to relocate the division to Texas. The other branches are newer, with Maryland opening in 1989 and Arizona in 1996. There are 55 employees in San Antonio, and 40 in each of the other two branches.

\section{INTERNATIONAL SITUATION}

Judith Lund, CEO, is meeting with Frank Rose, COO, Lawrence Wilson, VP for HR, Joelle Lamy, Chief of the Global Operations, and the Presidents of the three Divisions (Mark Thorn, Manufacturing, Serena Tibaldo, Creative Development, and Mark Derrick, TS\&M).

Ms. Lund: I have called this very important meeting because we have just received the resignation of another returning expatriate, bringing the total to two this year. This culminates a year in which we have seen declining sales and increased turbulence in our international staffing. I'm expecting that we can have an intensive review of our international positions which will give us some insights as to what we have been doing and where we might need to make some improvements. I have asked Frank to summarize our international position and experience to date.

Mr. Rose: Thanks Judith. As you all know, our international operations got going quickly, and rapidly showed impressive returns. Lately, however, there have been many more problems than with the early experience, and many of these seem to have to do with various personnel problems. I'm not saying that these problems are the fault of HR or

Global Operations, but if we don't determine what is wrong and fix the problems quickly, then we might have to scale back our international position. This could also mean that the divisions would see their workload go down, with resulting cutbacks.

To get started, let's begin with Global Operations.

Ms. Lamy: Merci. For those of you who are not up-to-date on the specifics of our operations, let me start with some background.

\section{European Operations (located in Germany)}

Five people are developing the continental perspective and software for the Creative Development Division. Of these, two are U.S. expatriates and three are local nationals. Our thinking here is that the expatriates will bring expertise as to how we develop our software and materials, while the local nationals will bring local knowledge.

Eleven people are in final fabrication for the Manufacturing Division. Of these, one is a U.S. expatriate and ten 


\section{$\underline{1}$}

are local or third country nationals. The former chief of this section, Dick Jones, was sent overseas to serve for six months. Unfortunately he quit a month before his duty was over.

Twelve people are handling logistics and follow-up services for the Transportation, Service and Maintenance Division. Of these, three are U.S. expatriates and nine are local or third country nationals. The other returning expatriate who recently left our employment is Peter Schroeder, who was one of the expatriates in this office. He was the son of immigrant German parents who expressly asked for duty in Germany, but when we brought him back to work in our San Antonio office at the end of his three year tour, he worked there for only two months and went to work for the International Logistics Department of a German company whose headquarters is based in New York City.

\section{Asian Operations (located in China)}

Five people are developing the continental perspective and software for the Creative Development Division. Of these, one is a U.S. expatriate and four are local nationals. We are having some personnel problems in this division also which we will discuss later.

Seventeen people are in final fabrication for the Manufacturing Division. Of these, two are U.S. expatriates and fifteen are local or third country nationals.

Fourteen people are handling logistics and follow-up services for the Transportation, Service and Maintenance Division. Of these, three are U.S. expatriates and eleven are local or third country nationals.

Mr. Wilson: From an HR perspective, the international operation has been a nightmare. This is not to say that Ms. Lamy hasn't been extremely helpful, but as Ms. Lund mentioned earlier, we have two returning expatriates who have resigned shortly after they returned from their international assignments. Every time a valuable employee leaves our company, it costs us at least $150 \%$ of annual salary to replace that person.

We need to go back and review the rationale for these assignments independently and investigate what could be done on behalf of the company to avoid these incidents.

Ms. Lamy: I think Mr. Wilson made a good point as to how these resignations hurt the company financially. We also lose experts who have gained valuable knowledge and experience about the field that can't be measured by numbers. We need to analyze each phase of the international assignment process and see how the company and the workers have progressed during these phases. Our mistakes can be in any of these phases.

Mr. Lund: Let's start with Mr. Jones. As was mentioned earlier, Mr. Jones was assigned to the Manufacturing Division of the European Operation. Mr. Thorn, as the president of the Manufacturing department, could you please tell us more about the division and goals for Mr. Jones' assignment?

Mr. Thorn: The situation at the division hasn't been good for at least two years. There are multiple, interrelated problems. The most important is the quality of the manufactured products. The quality hasn't been satisfactory at all. There are many defects among final products that cause excessive rejects. There is also too much turnover in the plant.

Mr. Rose: Mr. Thorn, I am sorry to interrupt you, but isn't the strategy of the Manufacturing Division quality based?

Mr. Thorn: That's the main reason why production in European Operation has been so frustrating for us. It seems that regardless of whom we appoint as the chief, the situation doesn't change.

Ms. Rose: If I remember correctly, the previous chief was a local national who also quit on the task. Am I correct, Mr. Thorn?

Mr. Thorn: Yes you are. For years we had different expatriates from the US who led the Manufacturing Division in 
$\underline{1}$

European Operation. They usually served in short assignments of three to eight months. The current problems existed back then too, but in much more benign form. Ten months ago we decided that it was time to hand the leadership to a local national who had been with the division for three years. It would also cost less for the company if a local national was assigned to the position instead of an expatriate. The idea seemed to work in the beginning, but later the problems in the division became much more serious. We felt that the lack of expertise from the home country was the reason. In addition, the local national left our employment for another job. That is when the Human Resources Department was contacted and a notice about an opening for the position was sent to them.

Mr. Wilson: Since the opening was specific to the Manufacturing Division, the Headquarters' HR Department worked closely with the head of human resources for the Manufacturing Division, Judith Woods. But we mainly let the Manufacturing Department Division make the final decision. There were three candidates who were eligible to serve as an expatriate in the European Operation. Since the selected person would be the chief of Manufacturing Division, we assumed there was a strong emphasize on experience. Among the considered candidates, Mr. Jones had the most experience and he was chosen mainly for this reason. Since he was single, he traveled to Germany alone and took over the leadership of the division. We felt that if he worked out well we could send over a replacement in nine or twelve months.

Ms. Rose: Mr. Thorn, were there any improvements with Mr. Jones leading the department? Did the expertise help the division?

Mr. Thorn: Not as much as we hoped. There were some improvements, but the fundamental mission of Mr. Jones was not realized. I think this was the reason he resigned from the position. His letter of resignation stated how frustrated he was with the situation in the plant and he wanted to leave the position because he didn't think that it was going to change in near future.

Ms. Lund: All right. I would like to know more about Mr. Schroeder. Ms. Lamy, you said that he was working for TS\&M Department. When was he assigned to the position?

Ms. Lamy: Mr. Schroeder was assigned to one of the three expatriate positions in the TS\&M Division of European Operation three years and two months ago. His appointment was designed for three years.

Mr. Wilson: Mr. Schroeder had been with the TS\&M Headquarters located in San Antonio, Texas for more than twenty years at the time of his appointment. He traveled to Germany with his spouse and three children. He was provided with a very nice house comparable to his stateside house, and we paid for his children to be enrolled at an American school in Bohn. We provided him with a car and driver, and even helped with a country club membership.

Ms. Rose: Wasn't that pretty expensive?

Mr. Derrick: Well, yes, but it's what expected. And it only lasts until he's reassigned back to the states. Mr. Schroeder made over ten trips back to the states during the three year period because of his elderly in-laws. Every time he came back he visited the TS\&M Headquarters in San Antonio and updated the management about the situation in Germany. He seemed happy about his position and was a very motivated employee.

Ms. Lund: Where did Mr. Schroeder work after his duty was over?

Mr. Derrick: After the completion of his trip he was appointed to his previous job in San Antonio. He worked for headquarters for two months and resigned last week. We were very surprised. We didn't expect it at all since Mr. Schroeder enjoyed his duty in Germany and we thought he would stay and work with us for many more years. His letter of resignation doesn't state a specific reason for his leave.

Ms. Lund: Ms. Lamy, please tell us more about the problems in the Asian Operation? We will come back to Mr. Jones and Mr. Schroeder's cases later. I would like to know more about the problems in China. 
$\underline{1}$

Ms. Lamy: The personnel problems we are having with the Asian Operation are in the Creative Development Division. We really would like to repatriate the division leader, Dr. Bryan Williams, but he wants to be stay there for at least three more years until he can retire. We hope to resolve this problem sometime soon.

Ms. Tibaldo: Dr. Williams is a senior employee who received his Ph.D. from Stanford University in 1972. Before his assignment to China, which was fifteen years ago, he worked for the Creative Development Division in the California Branch.

Mr. Rose: What projects has Dr. Williams worked on during his assignment?

Ms. Tibaldo: Dr. Williams is currently working on a project called "Effective Use of Calculators in the Classroom." His team consists of four newly graduated Chinese students.

Mr. Lund: What is the reason we are trying to call him back? Are there problems with his performance?

Ms. Tibaldo: The team hasn't been creating new ideas and innovations. We are losing our market share in the Asian markets. There is a strong competitor called New Education Services that entered the market last year. They seem to have better understanding of the Chinese education system, and they have better ways of teaching through new technology in the classrooms. We are not losing money at this moment, but we will be in the next quarter if things don't turn around somehow.

The second reason that we are trying call back Dr. Williams is that there has been a lot of friction between him and his fellow Chinese workers. They seem to disagree on almost all areas of development of various products.

Ms. Lund: Hmm... It seems like there are lot of problems in our international branches that need our immediate attention. Since it is already past lunch time, how about we take an hour break for lunch and meet back here at 1:30pm. When we get back we will go over each case more carefully and determine how we can improve what's going on.

\section{REFERENCE}

1. Schuler. R. S. and S.E. Jackson, "Linking competitive Strategy with Human Resources Management Practices," Academy of Management Executives, 1 (August, 1987), p.213.

\section{NOTES}


$\underline{1}$

NOTES 